Article

\title{
European Financial Services SMEs: Language in Their Sustainability Reporting
}

\author{
Esther Ortiz-Martínez *(D) and Salvador Marín-Hernández \\ Department of Accounting and Finance, University of Murcia, 3100 Murcia, Spain; salvlau@um.es \\ * Correspondence: esther@um.es; Tel.: +34-868-887-925
}

Received: 29 August 2020; Accepted: 8 October 2020; Published: 12 October 2020

check for updates

\begin{abstract}
In this study we concentrate on the segment of small companies in the financial sector in Europe. Services in this sector are developing rapidly and are not necessarily provided only by traditional banks and financial companies. Many nonfinancial companies provide financial services, and this may open the sector to additional risk. In this context, the aspects of both financial and nonfinancial reporting are important and need to be taken into consideration as a whole to provide a complex picture of a particular institution. The goal of this paper is to analyze sustainability reporting according to the Global Reporting Initiative (GRI) by European financial services small and medium-sized enterprises (SMEs). First, we conducted a descriptive analysis of the features of nonfinancial information and its assurance, studying a sample of all European SMEs reporting according to the GRI from 2016 to 2018. Then, we chose only financial services SMEs to apply lexical analysis to their narrative reporting based on a corpus of 102,056 words. We conclude that nonfinancial information does not have the same importance as traditional financial information, and this sustainability reporting only complies with the minimum requirements. Thus, there is still a long way to go in this field.
\end{abstract}

Keywords: European financial services; SMEs; nonfinancial information; sustainable reporting; disclosure; lexical analysis; nonfinancial reporting

\section{Introduction}

Initially, disclosure of nonfinancial information was voluntarily assumed by companies, mainly large global ones. The European Commission decided that the heterogeneity in this field was an inconvenience for transparency and comparability, so it required the compulsory issuance of nonfinancial information by big European groups [1]. Although the transposition of this directive can vary and includes certain flexibility in order to be adopted by each Member State, no state has extended the obligation of issuing this sustainable information to small and medium-sized enterprises (SMEs) [2]. Bearing in mind that most of the companies in Europe are SMEs, it is important to study the nonfinancial information that they provide because disclosure of nonfinancial information is a way to improve companies' transparency and communication of social and ethical practices. The first contribution of this paper is to show which European SMEs are disclosing sustainability reports according to the Global Reporting Initiative (GRI) voluntarily, which will add important knowledge to this field of research traditionally based on large companies.

SMEs are the backbone of the European economy and are traditionally dependent on bank loans for their external financing. The last financial crisis and now the situation generated by COVID-19 have increased both the need for financial resources and the difficulties in accessing it. The European Commission highlights these difficulties and promotes the provision of suitable alternatives to bank loans, so it enacted a specific regulation "to make SMEs more visible to investors and markets more attractive and accessible for SMEs. Regulatory changes will keep the right balance between prudential 
regulation and financing of SMEs, and between investor protection and tailored measures for SMEs" [3]. This sector is also in the spotlight of transparency after the recent crisis and has an additional obligation with society to try to balance the unequal distribution of information [4]. We focused our study on European financial services SMEs that provide sustainability reports according to GRI standards. The development of this sector is linked to economic growth [5], and the effect of the recent crisis on bank credit has increased the importance of other types of financial resources, such as trade credit [6]. Thus, the recent evolution of the financial sector has turned to SMEs to provide these services because their traditional problems in obtaining financial resources can be more easily solved by other SMEs [7]. Although at first sight the small size can seem to be a limitation to operating in the financial sector, it can be an important advantage because specializing as another SME or in retail services in order to provide a more similar service is seen as a positive way to attract SMEs to this sector [7]. Banks and, by extension, financial services companies are expected to approach climate risks and other risks related to sustainability in the same way that they approach any other financial risks [8].

The development of regulations in Europe to require sustainability reporting by financial services companies and obtain financial resources is under discussion, and recently a roadmap of regulation on taxonomy-related disclosures was launched by undertaking the reporting of nonfinancial information included in the European Commission's Action Plan on financing sustainable growth [9]. European financial sector companies have their own regulatory and supervisory bodies that do not depend on their size in terms of national and international financial compliance, although groups of European listed companies are directly regulated by European Union-International Financial Reporting Standards (EU-IFRS). IFRS also include requirements on disclosure as a response to the need for high-quality standards in order to be endorsed in Europe. In this line, in 2018 the European Securities and Markets Authority (ESMA) expanded its supervisory activities to nonfinancial information on environmental, social, and governance (ESG) matters assessing compliance with IFRS, and in 2019 it continued to focus on this disclosure. When speaking specifically about regulation of nonfinancial disclosure, large financial services companies are mainly considered entities of public interest in each Member State, which means that they are compulsorily required to disclose nonfinancial reporting according to Directive 2014/95/EU, although the specific requirements depend on its transposition by each Member State [1]. Hence, financial services SMEs that publish sustainability information do it voluntarily because they are not within the scope of the directive, and this field is not regulated.

Background information on the field of sustainability reporting of financial services SMEs is scarce and far from sufficient to develop requirements about it now when the European Commission is working on a review of nonfinancial reporting. Studying nonfinancial information is also difficult due to its mainly qualitative and narrative nature, which makes the information heterogeneous. Although most companies are using GRI standards, this does not suppose comparable homogeneous information. Hence, it is necessary to look for another type of methodology, such as lexical analysis, which means studying the words used in the narratives of sustainability reports by European financial sector SMEs, and this is the main objective of this study.

There are three main streams of theoretical framework on which this paper is based. The first refers to disclosure of nonfinancial information and global trends in this subject, such as the general use of GRI standards. Background information about the disclosure of nonfinancial information is mainly based on large companies, which are accustomed to listing because they try to inform their stakeholders and cope with the requirements established by the capital markets [10-12]. All global trends in this field have been adopted by large companies, which are globally shaping the features of disclosure with their voluntary reporting [13]. The generally accepted standards of nonfinancial information are GRI standards because "the GRI guidelines seem to fulfil the need for standards when reporting, identifying and implementing sustainable practices in the companies, since the GRI framework has become, de facto, the standard in sustainability reporting around the world" [14]. Reporting according to GRI standards means there is some kind of homogeneous disclosure as well as use of the GRI database [15-22]. 
Another important global trend in nonfinancial information is to verify it externally, or to gain assurance, which is linked to disclosure of these issues [23]. All of these practices have been extensively studied at the level of big companies, but background information on SMEs is scarce. Some studies have tried to obtain differences in disclosure between big companies and SMEs [24]. SMEs have fewer resources to report nonfinancial information [10], which does not mean that they do not behave in a sustainable way or do not have a sustainable culture. Studies have also argued that SMEs adopt better corporate social responsibility (CSR) practices, although they do not issue information about it [25]. Until recently, all sustainable reporting was issued voluntarily, but for a few years the European Union has made some kind of nonfinancial information on large companies compulsory [1], and some SMEs issue this information due to the influence of large companies [26] or because they want to gain a competitive advantage [12].

Currently, important work is being done to advise SMEs on how to voluntarily issue nonfinancial information. This is being done by regulators (such as the European Commission), the regulators' advisors (the European Financial Reporting Advisory Group (EFRAG) advises the European Commission, focusing on disclosure requirements), and professional organizations (the International Federation of Accountants (IFAC) and active organizations representing European SMEs such as the European Federation of Accountants and Auditors for SMEs (EFAA for SMEs) and SMEunited). However, the literature on sustainability reporting by SMEs is scarce and mainly based on a single research method, surveys, which means there is a need for further studies that combine other methods to add additional conclusions about this subject [27]. In this line, we point out the situation of voluntary sustainability reporting according to the GRI by European SMEs, which provides another point of view in a field of research traditionally based on large companies.

Second, there is background information focused on disclosure of financial services companies due to their important role in the economy. This sector has traditionally been a determinant of social issues of companies [28-30] because the information being issued depends on the kind of activity of the firm. Financial services companies are vital agents in the economy, so they are a benchmark for greater transparency [31-33]. They are also under special supervision and regulation in each country, with specific requirements on top of those applied for nonfinancial entities [34], and there can be an effect of the type of market economy on banks' disclosure (coordinated or liberal market economy) [35]. This vital activity and the effects of the recent crisis have increased research on the relationship between social responsibility and profitability in financial services companies and companies operating in other sectors [36-43]. Nowadays, there is also "ethical banking" in comparison to "conventional banking" because it is supposed to be more responsible and issue more information, both financial and nonfinancial, in response to stakeholders [44,45]. Notwithstanding ethical banking, traditional banking is supposed to take care of different aspects of its social responsibility such as consumer satisfaction [46] and the opinions of providers of financial resources [47]. The European Commission is promoting alternative financial plans for SMEs, trying to make it easier for SMEs to access markets [3], while not forgetting investor protection, which also includes sustainable reporting to respond to the increasing pressure to provide nonfinancial information [48].

The third theoretical framework is related to the methodology that we used in this paper: lexical analysis. The area of study, disclosure of nonfinancial information, is complex because it mainly consists of heterogeneous qualitative and narrative information. It is true that most companies are using GRI standards, but this does not mean there is comparable information, as there are different levels of adherence, and the formats of presenting the information can be quite diverse and flexible. Hence, analyzing disclosure implies many problems, which the majority of studies have tried to solve using content analysis or disclosure indices to measure this information (one recent study using indices is [49]), or to check if there is any relationship between disclosure and other features, although there are proven disadvantages when using this methodology [50]. Lexical analysis has been used in research having to do with semantics and language in a variety of fields, such as in [51,52], which strictly refer to language skills, as well as in analyzing qualitative narrative information in the field of economics, 
such as [53], which examined statements by the chairman and CEO in BP plc's Annual Report 2010 [54], which used lexicometric analysis to study a corpus comprising speeches of European Central Bank presidents; [55], which analyzed the results of open-ended interviews in the field of management; and [56], which used lexical analysis to try to extract the sentiments of a group of people to predict the movement of the stock market. Studies using lexical analysis of nonfinancial reporting are scarce, and none has analyzed disclosure by European financial sector SMEs. Mainly they have focused on big firms, such as [57], which conducted lexical analysis of annual reports of Shell plc.; [58], which reviewed previous research on sustainable banks for three periods depending on the financial crisis and used a descriptive bibliometric analysis and a co-word analysis to study the topics in the literature; [59], which applied lexical analysis to environmental disclosure of listed companies; [60], which asserted that the discourse included in the social reports of BP and IKEA was constructed to present the face that the companies wanted to show; and [61], which created two corpora from seven corporate governance reports of listed companies.

In this paper we use lexical analysis to study disclosure of nonfinancial information because it is mainly narrative, and this is a good way to obtain conclusions from the text provided and the words used to compose the narrative. The analysis is based on reporting by European financial sector SMEs, and the background on this field is scarce. Sustainability reporting in the financial sector is mainly inadequate and focused on financial aspects rather than on material issues, as highlighted by the UN when studying sustainability reporting in the financial sector [62]. Only a few of these initiatives of sustainability reporting provide a picture of all sustainability factors of financial companies [62]. In addition, the overwhelming majority of SMEs perceive sustainability reporting as a burden, and it appears that SMEs either do not have the capacity to comply or are reluctant to invest the necessary resources [63], so taking all this together, we propose the following research questions:

Research Question 1. Are European financial sector SMEs preparing their sustainability reports only in accordance with minimum nonfinancial disclosure requirements?

Research Question 2. Are European financial sector SMEs still more influenced by financial terms in their nonfinancial reporting?

The paper is organized as follows: first we describe the methodology, in the next section we discuss the results, and in the final section we wrap up the paper and describe the limitations and future research.

\section{Materials and Methods}

As the first goal of this paper is to point out the situation of sustainability reporting according to GRI voluntarily disclosed by European SMEs, we obtained the sample from the GRI database. Bearing in mind that GRI nonfinancial reporting standards are the most widely used all over the world and that SMEs in Europe are not compelled to issue this information, this database is a suitable resource to get these data. The search tool of the GRI database allows searches for nonfinancial reports according to firm size, and specifically reports issued by SMEs. We made our search on 11 November 2019 with the following criteria: firm size-SMEs; region-Europe; report type-GRI-Standards. Although previous versions of the GRI standards are included in the report type, these are the latest ones, published by GRI on 1 July 2018, replacing the GRI 4 version (https://www2.globalreporting.org/ standards/g4/Pages/default.aspx). In total, 116 organizations and 157 reports were found. This means that there are firms (or other types of organizations) that issued more than one report because these standards refer to 2016, 2017, 2018, and even 2019. As shown in Table 1, there are many sectors in which SMEs that issue nonfinancial information operate. 
Table 1. Nonfinancial information issued by European small and medium-sized enterprises (SMEs) according to Global Reporting Initiative (GRI).

\begin{tabular}{|c|c|c|c|c|c|c|c|}
\hline & & Frequency & $\%$ & & & Frequency & $\%$ \\
\hline \multirow{34}{*}{ Sector } & Real estate & 16 & 10.2 & \multirow{21}{*}{ Country } & Sweden & 26 & 16.6 \\
\hline & Tourism/leisure & 3 & 1.9 & & Slovenia & 1 & 0.6 \\
\hline & Energy utilities & 3 & 1.9 & & Belgium & 3 & 1.9 \\
\hline & $\begin{array}{l}\text { Food and beverage } \\
\text { products }\end{array}$ & 4 & 2.5 & & Andorra & 1 & 0.6 \\
\hline & Media & 3 & 1.9 & & Poland & 2 & 1.3 \\
\hline & Healthcare services & 7 & 4.5 & & Greece & 5 & 3.2 \\
\hline & Nonprofit services & 15 & 9.6 & & Austria & 5 & 3.2 \\
\hline & $\begin{array}{l}\text { Commercial } \\
\text { services }\end{array}$ & 10 & 6.4 & & Portugal & 3 & 1.9 \\
\hline & Telecommunications & 1 & 0.6 & & Russian & 1 & 0.6 \\
\hline & Textiles and apparel & 6 & 3.8 & & Denmark & 2 & 1.3 \\
\hline & $\begin{array}{l}\text { Forest and paper } \\
\text { products }\end{array}$ & 2 & 1.3 & & United Kingdom & 1 & 0.6 \\
\hline & Agriculture & 4 & 2.5 & & Netherlands & 8 & 5.1 \\
\hline & Conglomerates & 1 & 0.6 & & Norway & 1 & 0.6 \\
\hline & Mining & 2 & 1.3 & & Spain & 38 & 24.2 \\
\hline & Waste management & 8 & 5.1 & & Iceland & 3 & 1.9 \\
\hline & Aviation & 1 & 0.6 & & Germany & 18 & 11.5 \\
\hline & Universities & 1 & 0.6 & & Switzerland & 8 & 5.1 \\
\hline & Construction & 7 & 4.5 & & France & 4 & 2.5 \\
\hline & Energy & 7 & 4.5 & & Italy & 20 & 12.7 \\
\hline & Metal products & 3 & 1.9 & & Finland & 7 & 4.5 \\
\hline & Healthcare products & 6 & 3.8 & & Total & 157 & 100 \\
\hline & $\begin{array}{l}\text { Household and } \\
\text { personal products }\end{array}$ & 4 & 2.5 & \multirow{13}{*}{$\begin{array}{l}\text { Grouped } \\
\text { Sector }\end{array}$} & Real estate & 16 & 10.2 \\
\hline & Logistics & 3 & 1.9 & & Agriculture and mining & 6 & 3.8 \\
\hline & Public agencies & 2 & 1.3 & & Industry & 34 & 21.6 \\
\hline & Consumer durables & 1 & 0.6 & & Services & 38 & 24.2 \\
\hline & Water utilities & 1 & 0.6 & & $\begin{array}{l}\text { Public agencies } \\
\text { and services }\end{array}$ & 6 & 3.8 \\
\hline & $\begin{array}{l}\text { Construction } \\
\text { materials }\end{array}$ & 1 & 0.6 & & Nonprofit services & 15 & 9.6 \\
\hline & Automotive & 3 & 1.9 & & Financial services & 9 & 5.7 \\
\hline & Financial services & 9 & 5.7 & & $\begin{array}{c}\text { Construction and } \\
\text { construction materials }\end{array}$ & 8 & 5.1 \\
\hline & Railroads & 1 & 0.6 & & Energy & 7 & 4.5 \\
\hline & Retailers & 1 & 0.6 & & Other & 18 & 11.5 \\
\hline & Chemicals & 3 & 1.9 & & Total & 157 & 100 \\
\hline & Other & 18 & 11.5 & & - & - & - \\
\hline & Total & 157 & 100 & & - & - & - \\
\hline
\end{tabular}

Second, if we focus on the financial services sector, due to the specific features that we highlighted previously, we see that there are only nine reports to analyze. Hence, there are nine sustainability reports by European financial sector SMEs according to GRI, which supposes an important number of reports according to sector based on the breakdown in Table 1, and a percentage of reports (5.7\%) important in 
comparing nearly all sectors, with the exception of real estate, nonprofit services, commercial services, and others. It was necessary to group the sectors in order to get higher percentages of sustainability reports (grouped sector breakdown in Table 1).

Analyzing the language of these reports to see if they can be investigated more deeply, we find (Table 2) that only four out of nine reports are written in English, and the others are in the mother tongue. Although there is no English financial services SME in the sample, the majority of SMEs use English to prepare this information. It does not seem logical to prepare nonfinancial information according to GRI using the mother tongue in response to the market and stakeholders, but we must bear in mind that we focus on SMEs, and their goals in disclosing this information may not be so global.

Table 2. Nonfinancial information issued by European financial services SMEs according to GRI.

\begin{tabular}{|c|c|c|c|c|c|c|c|}
\hline & & Frequency & $\%$ & & & Frequency & $\%$ \\
\hline \multirow{7}{*}{ Country } & Sweden & 1 & 11.1 & \multirow{4}{*}{ Year } & 2016 & 1 & 11.1 \\
\hline & Iceland & 1 & 11.1 & & 2017 & 4 & 44.4 \\
\hline & Germany & 2 & 22.2 & & 2018 & 4 & 44.4 \\
\hline & Italy & 3 & 33.3 & & Total & 9 & 100 \\
\hline & Finland & 1 & 11.1 & \multirow{2}{*}{ Format of Report } & Pdf & 9 & 100 \\
\hline & Belgium & 1 & 11.1 & & Html & 0 & 0 \\
\hline & Total & 9 & 100 & \multirow{4}{*}{ Adherence Level } & In accordance core & 7 & 77.7 \\
\hline \multirow{6}{*}{$\begin{array}{l}\text { Language } \\
\text { of Report }\end{array}$} & Swedish & 1 & 11.1 & & $\begin{array}{l}\text { In accordance } \\
\text { comprehensive }\end{array}$ & 1 & 11.1 \\
\hline & English & 4 & 66.6 & & GRI referenced & 1 & 11.1 \\
\hline & German & 1 & 11.1 & & Total & 9 & 100 \\
\hline & Italian & 3 & 11.1 & \multirow{3}{*}{ Integrated Report } & Yes & 3 & 33.3 \\
\hline & \multirow{2}{*}{ Total } & \multirow{2}{*}{9} & \multirow{2}{*}{100} & & No & 6 & 66.6 \\
\hline & & & & & Total & 9 & 100 \\
\hline
\end{tabular}

Hence, only four European financial services SMEs issued nonfinancial information according to GRI standards and, fulfilling the methodological requirements, reported in English. We used all the data obtained from the GRI database during this period, so the sample is the whole population of European financial services SMEs that complied with GRI standards from 2016 to 2018 and wrote their reports in English. From the point of view of the lexical analysis methodology, the studied sample has the appropriate size, measured by the size of the corpus (number of words or tokens) compared to previous valid studies $[57,64,65]$.

We used SPSS to analyze the features of the nonfinancial information and its assurance, showing the frequencies in absolute values and percentages. All features were taken from the GRI database. After describing the features of the nonfinancial information issued by European financial services SMEs in English, we studied the narrative discourse of these reports, as this is the best way to analyze qualitative heterogeneous information. Hence, it was necessary to look for another type of methodology, such as lexical analysis, which involves studying the words used in the narrative. The reports are in PDF format in the GRI database, and to do a lexical analysis it is necessary to convert them into TXT files. We used free PDF-to-text software (https://pdftotext.com/es/) to get four TXT files correspondingly organized according to firm. These files made up the corpus for analyzing nonfinancial disclosure. To analyze the narrative reporting, we used another statistical methodology that allowed us to compare the disclosure to obtain the main characteristics of a corpus and find word patterns. The chosen tool was WordSmith Tools 7 software (version 7, Oxford University Press, Oxford, UK), published by Lexical Analysis Software and Oxford University Press since 1996. We used different utilities that this lexical analysis software offers, which are explained in the Results section. 


\section{Results}

\subsection{Features of Nonfinancial Information and Its Assurance of European Financial Services SMEs}

First, 5.7\% of all European SMEs that voluntarily disclosed nonfinancial information according to GRI (9 out of 157) operated in the financial services sector (Table 1). The most important sector in this sample was real estate companies (10.2\%; Table 1$)$, and financial services occupies an important position of nonfinancial information according to sector. The nine financial services companies that issued nonfinancial information came from different EU countries (Table 2). There are two effects to bear in mind. First, sometimes SMEs that need credit have to report on some sustainability aspects to align with banks' sustainability requirements. Second, these SMEs provide financial services, which means they have to report on their own sustainability [63]. As previously pointed out, only four of the nine used the English language to report their nonfinancial information, and five used their mother tongue, although it is supposed that these reports are published for global stakeholders (Table 2).

To get an idea of the importance of this type of SME in Europe, we can highlight that two of the four are asset managers, one in Germany and one in Finland. According to the European Fund and Asset Management Association [65], in 2017 there were 380 asset management companies in Germany (one of the leading European countries with this type of company) and 26 in Finland. Hence, bearing in mind that these numbers are not detailed by company size, we can say that these two SMEs are a good sample to study. The other two European financial services SMEs are a bank in Iceland, a state-owned bank created from an old bank during the last crisis (a national bank, thus its small size), and a provider of financial market infrastructure services in Belgium. The bank's main services are based on consumer, corporate, and private banking; mortgage loans, private equity, wealth management, and credit cards. The German asset manager offers one global investment platform focused on multi-asset alternative credit, real asset debt, and sustainable investments through a digital environment for retail investors. The Belgian provider of financial market infrastructure services acts as an international central securities depository (ICSD) and as the central securities depository (CSD) for some other securities. Retail investors can also have direct accounts in their local CSD. The Finnish asset manager offers asset management solutions and financial advice globally to private investors, institutions, professional athletes, and artists. Finally, the analyzed companies offer a valuable picture of the narrative discourse included in sustainability reports, taking into account particular niches in the financial industry. At the same time, these reports are comparable because all the companies are SMEs operating in the financial services sector, bearing in mind that the sector is one of the most important determinant variables influencing nonfinancial reporting [66-68].

As regards the adherence level, most of the nine European financial services SMEs (80\%) adjust their information to the core level of GRI, which is referred to as the "in accordance" core, and prefer not to prepare integrated reports (Table 2). Thus, it seems as if these companies try to issue nonfinancial information following the minimum established standards as highlighted by the UN when it studies sustainability reporting in the financial sector and says that it is not offering information about all sustainability factors of financial companies [69], even more if we are speaking about SMEs.

Bearing in mind the assurance of this information (Table 3), two-thirds of these financial services companies verified the disclosure externally. The predominant level of assurance is limited/moderate, and the assurance scope is a specified section as defined by GRI. The assurance providers in the analyzed reports were mainly accountants (55.5\%); one-third of verifications were done by one of the Big Four companies, KPMG (33.3\%), and one-third were done following the ISAE 3000 assurance standard. However, the financial services companies did not issue information about this assurance after they verified their nonfinancial information (at least four of them, or $44.4 \%$, did not have this information available; Table 3). 
Table 3. Features of nonfinancial assurance of European financial services SMEs.

\begin{tabular}{|c|c|c|c|c|c|c|c|}
\hline & & Frequency & $\%$ & & & Frequency & $\%$ \\
\hline \multirow{3}{*}{$\begin{array}{c}\text { External } \\
\text { Assurance }\end{array}$} & Yes & 6 & 66.6 & \multirow{3}{*}{$\begin{array}{l}\text { Type of } \\
\text { Assurance } \\
\text { Provider }\end{array}$} & Accountant & 5 & 55.5 \\
\hline & No & 3 & 33.3 & & Not available & 4 & 44.41 \\
\hline & Total & 9 & 100 & & Total & 9 & 100 \\
\hline \multirow{3}{*}{$\begin{array}{c}\text { Level of } \\
\text { Assurance }\end{array}$} & Not available & 4 & 44.4 & \multirow{3}{*}{$\begin{array}{l}\text { Assurance } \\
\text { Scope }\end{array}$} & Not available & 5 & 55.5 \\
\hline & Limited/moderate & 5 & 55.5 & & Specified sections & 4 & 44.4 \\
\hline & Total & 9 & 100 & & Total & 9 & 100 \\
\hline \multirow{5}{*}{$\begin{array}{l}\text { Assurance } \\
\text { Standard }\end{array}$} & Not available & 4 & 44.4 & \multirow{5}{*}{$\begin{array}{l}\text { Assurance } \\
\text { Provider }\end{array}$} & Not available & 4 & 44.4 \\
\hline & ISAE 3000 & 3 & 33.3 & & KPMG & 3 & 33.3 \\
\hline & AA1000AS & 1 & 11.1 & & Deloitte & 2 & 22.2 \\
\hline & National & 1 & 11.1 & & \multirow{2}{*}{ Total } & \multirow{2}{*}{9} & \multirow{2}{*}{100} \\
\hline & Total & 9 & 100 & & & & \\
\hline
\end{tabular}

\subsection{Lexical Analysis of Sustainability Reporting of European Financial Services SMEs}

First, we used the WordList application to obtain the principal characteristics of the text analyzed. The main features are shown in Table 4. Although the companies are in different countries and the reports are from different years, these data are comparable because all are SMEs and operate in the financial services sector. Finally, we analyzed 102,056 words, which are called tokens, and all together are defined as a corpus. The size of the corpus, and thus of the sample, is appropriate to apply lexical analysis (the number of analyzed words or tokens is always bigger than the corpus analyzed in previous valid studies $[57,64,65])$.

Table 4. Principal characteristics of analyzed sustainability reports.

\begin{tabular}{cccccccc}
\hline Corpus/SME & Country & Year & Words (Tokens) & $\begin{array}{c}\text { Types * } \\
\text { (Distinct Words) }\end{array}$ & $\begin{array}{c}\text { Type-Token } \\
\text { Ratio (TTR) }\end{array}$ & $\begin{array}{c}\text { Standardized } \\
* * \text { TTR }\end{array}$ & Sentences \\
\hline Corpus & - & - & 102,056 & 7927 & $7.77 \%$ & $40.63 \%$ & 3800 \\
\hline SME1 & Iceland & 2018 & 38,753 & 4214 & $10.87 \%$ & $38.01 \%$ & 1423 \\
\hline SME2 & Germany & 2018 & 29,795 & 3659 & $12.28 \%$ & $42.46 \%$ & 1150 \\
\hline SME3 & Belgium & 2017 & 23,728 & 3570 & $15.05 \%$ & $42.37 \%$ & 725 \\
\hline SME4 & Finland & 2016 & 9780 & 1870 & $19.12 \%$ & $41.37 \%$ & 502 \\
\hline
\end{tabular}

* Types: different words that are not repeated in the text. ${ }^{*}$ Standardized TTR: TTR that does not depend on different text lengths.

It can be seen that the four companies are in different European countries. There are no big differences between words in the reports of the last three years, except that in 2016 the reports were much briefer than in the following years. This may be due to the early application of GRI standards or to the fact that companies show greater effort "from year to year in giving more information in order to comply with the transparency principle, or at least to give this appearance" [57]. The same can be checked in the different words used in the reports, which are called "types" in this software, and in the type-token ratio (TTR), calculated as different words over total words, which increases when the number of total words decreases (Table 4). However, when the TTR is calculated without considering the extension of the whole text, standardized TTR, the largest number of different words, without repetition, is found in the latter reports, with the exception of the report of the Icelandic financial services company, which seems to repeat words more frequently although the report is the most extensive (more words and more sentences; Table 4). Perhaps more words are used to say the same thing, and the opposite was the case in the 2016 report; fewer words were used to say the important things, which were not repeated. Although, as mentioned, there is value in a 
reporting narrative, that does not mean it is an extensive report because a sustainability report is not for storytelling [70]. Previous studies on the relationship between disclosure length and greater readability, transparency, or complexity were inconclusive [71] and were not focused on financial services SMEs.

The next tool used in the lexical analysis was the word list (results are shown in Table 5). This counts the frequency of words used in the corpus, i.e., how often each word appears in the whole text, and their percentage of use in the text. The position is the ranking of the most frequently used words. We included in Table 5 the most significant frequent words for this analysis (the first position is included as an example). Only the word "risk" appeared in more than $1 \%$ of the cases in the corpus (1.04\%), in position 8 , followed by "bank" in position 12 and "management" in position 20. To classify these most frequent words, we created three groups: words that are basically related to financial meaning such as "risk", "bank", "management", "financial", "capital", "investment", "business", and "funds"; other words that have to do with the core sense of nonfinancial information, such as "employees", "sustainability", "board", "environmental", "committee", "governance", "pillar", and "GRI"; a group with words related to information and requirements, such as "information", "compliance", "reporting", "disclosures", and "requirement". This classification was based on the assignment of a certain term to a concept, which can be done in specialized languages, as in this case, when analyzing sustainability reporting; for example, the word "meager" is identified as a specialized term in the realm of finance, since it is very commonly used in expressions such as "meager economic recovery" and "meager 10\%" [71]. Although the word "pillar" is included in the financial group, it could also be included in the second group related to nonfinancial aspects, which we called sustainable most frequent words. This is due to the Basel II and III requirements, which ask for reporting on financial and nonfinancial items of these kinds of companies, so it contains both dimensions of the concept, financial and nonfinancial. Although these three groups of most frequent words were made following the assignment of terms to concepts in specialized languages [72], sometimes some words refer to more concepts and the assignment is not so simple.

The following results were obtained from the analysis of the most frequent words, shown in Tables 6-8. The number of occurrences of the search word (hits), occurrences of each word per 1000 words, and their dispersion are calculated. To establish comparisons, it is better to use hits per 1000 words as a homogeneous measurement. As can be seen, "financial" words are used the most: the occurrences per 1000 words were clearly the highest for these kinds of words. The most used was "risk" (10.16 times per 1000 words), followed by "bank", "management", and then a sustainable word, "sustainability" (3.75 times per 1000 words; Table 7) followed by other financial words: "financial", "capital", "investment", "business" (2.40 times per 1000 words), and then "employees", previously included in the group of sustainable words (2.29 times per 1000 words) and "GRI" (2.13 times per 1000 words). This means that what counts the most in sustainable reports is the financial information over the nonfinancial information, or at least the typical financial aspects of the business are highlighted more with the use of the language. These companies do not seem to include sustainable words in their vocabulary and, hence, in their culture. Although the four companies are in different countries and operate in different niches of financial services, the results are similar when classifying the most used words.

Analyzing the information on the use of these frequent words considering the four reports separately, we can see that some of the words appear to be used more because they are used very often in some reports, which increases the global frequency in the corpus. This is the case of the words "risk", "bank", and "capital" (20.15, 18.23, 6.80 per 1000 words; Table 6), which occur frequently in the report of the financial services company in Iceland. The word "sustainability" appears as the second most frequent in this group due to its use in the Finnish company's 2016 report, although it is only used in three of the four reports (8.10 per 1000 words; Table 7). Something similar happens with the word "employees", whose use increases due to the Finnish company's report (5.36 per 1000 words, Table 7). The case of the word "pillar" deserves some reflection because, although it is a frequent word in the corpus, the detailed analysis of the reports showed that it was only used in two, and essentially 
only in one because the frequency of use in the other was very low. Thus, "pillar" was exclusively used by the financial services company in Iceland in its 2018 report (Table 7). Another example is the term "GRI", which would be expected to appear in all of the reports, given that all are prepared according to GRI standards, yet it did not appear in one report, which is one of the most recent ones (Table 7).

Table 5. Word analysis of sustainability reports.

\begin{tabular}{|c|c|c|c|}
\hline Position & Word & Frequency & $\%$ \\
\hline 1 & The & 5001 & $4.90 \%$ \\
\hline 8 & Risk & 1103 & $1.08 \%$ \\
\hline 12 & Bank & 899 & $0.89 \%$ \\
\hline 20 & Management & 566 & $0.55 \%$ \\
\hline 24 & Financial & 374 & $0.37 \%$ \\
\hline 26 & Capital & 356 & $0.35 \%$ \\
\hline 41 & Investment & 276 & $0.27 \%$ \\
\hline 44 & Business & 261 & $0.26 \%$ \\
\hline 45 & Employees & 248 & $0.24 \%$ \\
\hline 46 & Sustainability & 234 & $0.23 \%$ \\
\hline 52 & Board & 207 & $0.2 \%$ \\
\hline 53 & Information & 206 & $0.2 \%$ \\
\hline 69 & Responsibility & 157 & $0.15 \%$ \\
\hline 73 & Compliance & 153 & $0.15 \%$ \\
\hline 74 & Reporting & 147 & $0.14 \%$ \\
\hline 75 & Disclosures & 147 & $0.14 \%$ \\
\hline 76 & Requirements & 145 & $0.14 \%$ \\
\hline 77 & environmental & 145 & $0.14 \%$ \\
\hline 79 & Committee & 143 & $0.14 \%$ \\
\hline 82 & Governance & 135 & $0.13 \%$ \\
\hline 83 & Pillar & 134 & $0.13 \%$ \\
\hline 84 & GRI & 133 & $0.13 \%$ \\
\hline 86 & Funds & 131 & $0.13 \%$ \\
\hline
\end{tabular}


Table 6. Statistics of the most important financial words in sustainability reports.

\begin{tabular}{|c|c|c|c|c|c|c|c|c|c|c|c|c|}
\hline \multirow{2}{*}{$\begin{array}{c}\text { Words } \\
\text { Corpus/SME }\end{array}$} & \multicolumn{3}{|c|}{ Risk } & \multicolumn{3}{|c|}{ Bank } & \multicolumn{3}{|c|}{ Management } & \multicolumn{3}{|c|}{ Financial } \\
\hline & Hits * & Per 1000 ** & Dis. & Hits & Per 1000 & Dis. & Hits & Per 1000 & Dis. & Hits & Per 1000 & Dis. \\
\hline Corpus & 1103 & 10.16 & 0.831 & 899 & 8.28 & 0.796 & 566 & 5.22 & 0.839 & 374 & 3.45 & 0.811 \\
\hline SME1 & 931 & 20.15 & 0.818 & 842 & 18.23 & 0.777 & 237 & 5.13 & 0.711 & 170 & 3.68 & 0.699 \\
\hline SME2 & 95 & 3.25 & 0.728 & 28 & 0.96 & 0.753 & 187 & 6.40 & 0.797 & 114 & 3.90 & 0.796 \\
\hline SME3 & 68 & 2.88 & 0.497 & 28 & 1.19 & 0.630 & 103 & 4.36 & 0.814 & 59 & 2.50 & 0.652 \\
\hline SME4 & 9 & 0.95 & 0.340 & 1 & 0.11 & 0.000 & 39 & 4.10 & 0.736 & 31 & 3.26 & 0.802 \\
\hline Corpus/SME & Hits * & Per 1000 ** & Dis. & Hits & Per 1000 & Dis. & Hits & Per 1000 & Dis. & Hits & Per 1000 & Dis. \\
\hline Corpus & 356 & 3.28 & 0.630 & 276 & 2.54 & 0.852 & 261 & 2.40 & 0.834 & 131 & 1.21 & 0.820 \\
\hline SME1 & 314 & 6.80 & 0.595 & 41 & 0.89 & 0.618 & 80 & 1.73 & 0.729 & 69 & 1.49 & 0.727 \\
\hline SME2 & 11 & 0.38 & 0.665 & 169 & 5.78 & 0.755 & 96 & 3.29 & 0.806 & 38 & 1.30 & 0.607 \\
\hline SME3 & 16 & 0.68 & 0.646 & 16 & 0.68 & 0.410 & 58 & 2.46 & 0.820 & 10 & 0.42 & 0.553 \\
\hline SME4 & 15 & 1.58 & 0.435 & 50 & 5.26 & 0.653 & 27 & 2.84 & 0.669 & 14 & 1.47 & 0.646 \\
\hline
\end{tabular}

* Hits: number of occurrences of the search word. ** Per 1000 words: number of occurrences per 1000 words. Dis., dispersion.

Table 7. Statistics of the most important sustainable frequent words in sustainability reports.

\begin{tabular}{|c|c|c|c|c|c|c|c|c|c|c|c|c|}
\hline \multirow{2}{*}{$\begin{array}{c}\text { Words } \\
\text { Corpus/SME }\end{array}$} & \multicolumn{3}{|c|}{ Employees } & \multicolumn{3}{|c|}{ Sustainability } & \multicolumn{3}{|c|}{ Board } & \multicolumn{3}{|c|}{ Environmental } \\
\hline & Hits * & Per $1000 * *$ & Dis. & Hits & Per 1000 & Dis. & Hits & Per 1000 & Dis. & Hits & Per 1000 & Dis. \\
\hline Corpus & 248 & 2.29 & 0.802 & 234 & 3.75 & 0.732 & 207 & 1.91 & 0.732 & 145 & 1.34 & 0.733 \\
\hline SME1 & 12 & 0.26 & 0.184 & - & - & - & 99 & 2.14 & 0.563 & 1 & 0.02 & 0.000 \\
\hline SME2 & 92 & 3.15 & 0.688 & 147 & 5.03 & 0.722 & 62 & 2.12 & 0.718 & 64 & 2.19 & 0.612 \\
\hline SME3 & 93 & 3.94 & 0.704 & 10 & 0.42 & 0.528 & 37 & 1.57 & 0.498 & 57 & 2.41 & 0.608 \\
\hline SME4 & 51 & 5.36 & 0.551 & 77 & 8.10 & 0.682 & 9 & 0.95 & 0.340 & 23 & 2.42 & 0.489 \\
\hline
\end{tabular}


Table 7. Cont.

\begin{tabular}{|c|c|c|c|c|c|c|c|c|c|c|c|c|}
\hline \multirow{2}{*}{$\begin{array}{c}\text { Words } \\
\text { Corpus/SME }\end{array}$} & \multicolumn{3}{|c|}{ Committee } & \multicolumn{3}{|c|}{ Governance } & \multicolumn{3}{|c|}{ Pillar } & \multicolumn{3}{|c|}{ GRI } \\
\hline & Hits * & Per $1000 * *$ & Dis. & Hits & Per 1000 & Dis. & Hits & Per 1000 & Dis. & Hits & Per 1000 & Dis. \\
\hline Corpus & 143 & 1.44 & 0.648 & 135 & 1.24 & 0.730 & 134 & 1.78 & 0.785 & 133 & 2.13 & 0.810 \\
\hline SME1 & 103 & 2.23 & 0.452 & 29 & 0.63 & 0.630 & 133 & 2.88 & 0.783 & - & - & - \\
\hline SME2 & 7 & 0.24 & 0.270 & 74 & 2.53 & 0.639 & 1 & 0.03 & 0.000 & 68 & 2.33 & 0.767 \\
\hline SME3 & 33 & 1.40 & 0.485 & 22 & 0.93 & 0.665 & - & - & - & 53 & 2.25 & 0.751 \\
\hline SME4 & - & - & - & 10 & 1.05 & 0.419 & - & - & - & 12 & 1.26 & 0.184 \\
\hline
\end{tabular}

${ }^{*}$ Hits: number of occurrences of the search word. ${ }^{* *}$ Per 1000 words: number of occurrences per 1000 words. Dis., dispersion.

Table 8. Statistics of the most important frequent words related to information and compliance in sustainability reports.

\begin{tabular}{|c|c|c|c|c|c|c|c|c|c|c|c|c|}
\hline \multirow{2}{*}{$\begin{array}{c}\text { Words } \\
\text { Corpus/SME }\end{array}$} & \multicolumn{3}{|c|}{ Information } & \multicolumn{3}{|c|}{ Compliance } & \multicolumn{3}{|c|}{ Reporting } & \multicolumn{3}{|c|}{ Disclosures } \\
\hline & Hits * & Per $1000 * *$ & Dis. & Hits & Per 1000 & Dis. & Hits & Per 1000 & Dis. & Hits & Per 1000 & Dis. \\
\hline Corpus & 206 & 1.90 & 0.813 & 153 & 1.41 & 0.751 & 147 & 1.35 & 0.841 & 147 & 1.35 & 0.806 \\
\hline SME1 & 84 & 1.82 & 0.703 & 48 & 1.04 & 0.572 & 42 & 0.91 & 0.681 & 118 & 2.55 & 0.759 \\
\hline SME2 & 85 & 2.91 & 0.741 & 66 & 2.26 & 0.526 & 56 & 1.92 & 0.829 & 11 & 0.38 & 0.356 \\
\hline SME3 & 10 & 0.42 & 0.419 & 36 & 1.52 & 0.725 & 28 & 1.19 & 0.747 & 17 & 0.72 & 0.651 \\
\hline SME4 & 27 & 2.84 & 0.620 & 3 & 0.32 & 0.299 & 21 & 2.21 & 0.600 & 1 & 0.11 & 0.000 \\
\hline
\end{tabular}

\begin{tabular}{cccc}
\hline Words & \multicolumn{3}{c}{ Requirements } \\
\hline Corpus/SME & Hits ${ }^{*}$ & Per $\mathbf{1 0 0 0} * *$ & Dis. \\
\hline Corpus & 145 & 1.34 & 0.855 \\
\hline SME1 & 101 & 2.19 & 0.815 \\
\hline SME2 & 34 & 1.16 & 0.730 \\
\hline SME3 & 6 & 0.25 & 0.582 \\
\hline SME4 & 4 & 0.42 & 0.465 \\
\hline
\end{tabular}

* Hits: number of occurrences of the search word. ${ }^{* *}$ Per 1000 words: number of occurrences per 1000 words. Dis., dispersion. 
Analyzing Table 8, with the statistics of the most important frequent words related to information and compliance in the sustainability reports, there was one report in which they had less importance, as was previously obtained, that of the Belgian company from 2017. The most used words in the other three reports were those generally obtained as the most frequent words; hence, they follow the general pattern. For example, "information" showed higher frequency per 1000 words in the German and Finnish reports (SME2 and SME4: 2.91 and 2.84, respectively; Table 8) and so on with the other words.

The last three tables of this analysis (Tables 9-11) include the results obtained from the concordance tool of the lexical analysis. The last step is to analyze the most frequent words in their context. This means counting the number of times one word is found in the neighborhood of the chosen word. This tool allows us to discover whether or not the most frequent words are related to the disclosure they supposedly refer to. The method of considering the relationships between certain words and the other words that appear a sentence was used in previous studies, such as [73]. All the tables of concordance include the first eight words with the most important relationships (in the tables, they are in positions from 1 to 8 , and position 1 is always the most frequent word analyzed). In the case of the word "requirements", its position 8 showed very low frequency, and it was not included in Table 11.

Table 9. Concordance of most important financial frequent words in sustainability reports.

\begin{tabular}{ccccccccc}
\hline Position & Word & Total & Word & Total & Word & Total & Word & Total \\
\hline 1. & Bank & 936 & Risk & 1538 & Management & 610 & Financial & 394 \\
\hline 2. & Risk & 254 & Bank & 254 & Risk & 252 & Services & 33 \\
\hline 3. & Arion & 190 & Management & 252 & Asset & 55 & Report & 33 \\
\hline 4. & 2018 & 139 & Credit & 210 & Bank & 53 & Statements & 28 \\
\hline 5. & Disclosures & 104 & 2018 & 160 & Approach & 51 & Risk & 26 \\
\hline 6. & Pillar & 97 & Disclosures & 147 & Capital & 48 & Institutions & 25 \\
\hline 7. & Capital & 64 & Pillar & 118 & With & 38 & Bank & 25 \\
\hline 8. & Management & 53 & Arion & 110 & Senior & 36 & Undertakings & 25 \\
\hline Position & Word & Total & Word & Total & Word & Total & Word & Total \\
\hline 1. & Capital & 450 & Investment & 302 & Business & 279 & Funds & 149 \\
\hline 2. & Bank & 64 & Responsible & 47 & Risk & 36 & Investment & 21 \\
\hline 3. & Risk & 64 & Sustainable & 22 & With & 29 & Bank & 15 \\
\hline 4. & Requirements & 64 & Funds & 21 & Bank & 20 & Pension & 13 \\
\hline 5. & Buffer & 51 & Platform & 21 & Travel & 17 & Sustainable & 12 \\
\hline 6. & Requirement & 50 & Fund & 18 & Units & 17 & Capital & 11 \\
\hline 7. & Management & 48 & Process & 18 & Management & 17 & With & 10 \\
\hline 8. & Adequacy & 32 & Into & 17 & That & 13 & Risk & 10 \\
\hline & $*$ Total: number of times the word was found in the neighborhood of the search word. &
\end{tabular}


Table 10. Concordance of most important sustainable frequent words in sustainability reports.

\begin{tabular}{|c|c|c|c|c|c|c|c|c|}
\hline Position & Word & Total * & Word & Total & Word & Total & Word & Total \\
\hline 1. & Employees & 260 & Sustainability & 258 & Board & 241 & Environmental & 157 \\
\hline 2. & Time & 19 & Report & 129 & Committee & 53 & Social & 51 \\
\hline 3. & With & 16 & 2018 & 82 & Executive & 44 & Impacts & 15 \\
\hline 4. & That & 15 & Information & 36 & Directors & 42 & Impact & 14 \\
\hline 5. & Have & 15 & Supplementary & 32 & Management & 27 & Group & 12 \\
\hline 6. & Permanent & 15 & Topics & 25 & Risk & 27 & Assessment & 12 \\
\hline 7. & Total & 12 & This & 22 & Bric & 19 & Footprint & 12 \\
\hline 8. & Their & 12 & Clients & 21 & Policy & 17 & Economic & 11 \\
\hline Position & Word & Total & Word & Total & Word & Total & Word & Total \\
\hline 1. & Committee & 203 & Governance & 147 & Pillar & 148 & GRI & 133 \\
\hline 2. & Board & 53 & Corporate & 46 & Risk & 118 & 2017 & 25 \\
\hline 3. & Credit & 40 & Risk & 15 & Disclosures & 105 & Index & 24 \\
\hline 4. & Risk & 25 & Data & 12 & 2018 & 97 & Responsibility & 24 \\
\hline 5. & Management & 24 & Social & 11 & Bank & 97 & With & 19 \\
\hline 6. & Executive & 21 & Policy & 11 & Arion & 94 & Disclosure & 18 \\
\hline 7. & Level & 17 & Body & 11 & Capital & 24 & Reporting & 16 \\
\hline 8. & Arion & 14 & Environmental & 11 & Requirements & 21 & Report & 14 \\
\hline
\end{tabular}

* Total: number of times the word was found in the neighborhood of the search word.

Table 11. Concordance of most important frequent words related to information and compliance in sustainability reports.

\begin{tabular}{|c|c|c|c|c|c|c|}
\hline Position & Word & Total * & Word & Total & Word & Total \\
\hline 1. & Information & 214 & Compliance & 165 & Reporting & 152 \\
\hline 2. & Report & 48 & With & 33 & Risk & 22 \\
\hline 3. & Sustainability & 36 & Risk & 27 & Financial & 22 \\
\hline 4. & Security & 35 & Officer & 19 & Sustainability & 16 \\
\hline 5. & Risk & 31 & Control & 18 & Report & 14 \\
\hline 6. & 2018 & 27 & Regulatory & 14 & Bank & 13 \\
\hline 7. & Supplementary & 26 & Management & 13 & Internal & 12 \\
\hline 8. & Bank & 18 & 2018 & 13 & Period & 11 \\
\hline Position & Word & Total & Word & Total & & \\
\hline 1. & Disclosures & 148 & Requirements & 155 & & \\
\hline 2. & Risk & 148 & Capital & 64 & & \\
\hline 3. & Pillar & 106 & Regulatory & 25 & & \\
\hline 4. & Bank & 104 & With & 21 & & \\
\hline 5. & 2018 & 98 & Bank & 21 & & \\
\hline 6. & Arion & 96 & Risk & 19 & & \\
\hline 7. & Credit & 21 & Buffer & 15 & & \\
\hline 8. & Management & 18 & - & - & & \\
\hline
\end{tabular}


The words that were previously grouped as financial terms in the analysis of the most frequent words are related to the same type of financial words: bank-risk, management-risk, financial-services, capital-bank-risk, business and risk, and funds-investment-bank (all are in position 1, 2, or 3 in Table 9, which means they appear next to each other). The only most frequent financial word included previously that was more frequently related to other sustainable terms was "investment", appearing in the reports with "responsible" and "sustainable" (Table 9).

The most frequent words about sustainable aspects appeared fewer times that the financial ones (Table 10), and the concordance shows the following:

- The word "employees" is not related to other important words.

- The word "sustainability" is linked mainly to "report", due to the requirement to issue sustainable information, and is totally consistent with the results obtained in Table 11.

- The words "committee" and "board", "environmental" and "social", "governance" and "corporate" are found frequently in the same neighborhood, a result that is totally logical.

- The word "pillar" appears in the neighborhood with two other words, "risk" and "disclosures", as is also seen in Table 11 with "disclosures". This result proves that "pillar" is a word that comes from the Basel II and III requirements regarding these aspects.

- Finally, the most important link is found between "GRI", "2017", and "index", as reports include the GRI index to show that they are elaborated according to GRI standards.

The majority of results included in Table 11 go further in the importance of the words "compliance", "requirements", "disclosures", and "risk". According to GRI good practices for SMEs, sustainability reporting has to comply with the following checklist: it describes the sustainable development and draws objective and available information and measures of sustainable development, presents the performance of sustainable conditions and goals and the magnitude of the contribution to (un)sustainability, and describes the relationship between sustainability and long-term organizational strategy, risks, and opportunities [74]. Thus, if we use this lexical analysis to understand whether these financial services SMEs properly developed their sustainability reporting, the obtained results show that although they used some specific words to meet the minimum requirements, the financial dimension of reporting continues to be more important, and the other information is used to increase the length of the report but still does not reflect significant environmental and social impacts. According to previous studies [75], sustainability reporting in financial companies has as the highest priorities those directly related to their business operations.

\section{Discussion}

Our analysis is based on European SMEs included in the GRI database, hence the population of SMEs that voluntarily use GRI standards, although only between 10 and $15 \%$ of sustainability reports in the database from 2017 to 2018 came from SMEs [76]. Then, we focused on European SMEs operating in the financial services sector. Bearing in mind their specific activity, sustainability reports by European financial sector SMEs represent an important percentage of reports in comparison with nearly all other sectors $(5.7 \%)$.

The results obtained from the lexical analysis lead us to think that the answer to our first research question is yes because there is no significant use of symbolic concepts in the narrative discourse in the reports analyzed; hence, there is minimum compliance with nonfinancial requirements. Opposite results were obtained by the authors of [53] after applying a lexicometric analysis to speeches delivered by European Central Bank presidents, although in this case we analyzed sustainability reporting.

Although initially it may be thought that sustainability reports are specific for each company, the broader corpus analysis suggests they were prepared similarly and used the same template [52], even more if it is pointed out that the four companies are in different countries and, although operating in financial services, are focused on different niches. As the sector is a strongly determinant variable of nonfinancial reporting [66-68], the analyzed reports follow the same pattern. Financial services 
companies not only operate in the same sector, but they also have their own regulatory and supervisory bodies. In this case the sector is decisive in following the same financial trend in sustainability information, and as found in KPMG's 2017 survey, financial services companies are in last place in corporate responsibility reporting [77].

These financial services companies are still imbued with traditional financial objectives and information. This means that what counts most in sustainable reports is financial information over nonfinancial, or at least the typical financial aspects of the business in this important sector are highlighted more through the language used. The analysis of the most frequent words in context shows that all financial terms are related to other financial terms. Hence, our second research question is supported. These results are the same as those obtained in previous studies, although in developing countries, based on financial services companies, because it is argued that the most important priorities of these enterprises are those directly related to their business operations [75].

Although a first view of sustainable reporting may show that companies try to exert more effort to increase the extent of their disclosure, the deep lexical analysis of these reports shows that the language used is not so extensive or rich, as some words are repeated many times, which highlights the problem of the lack of content in sustainability information. This shows evidence of the gap that still exists between financial and nonfinancial information and takes us to the same question posed by other researchers: "If it is like this for disclosing firms, what is happening in the case of nondisclosing firms?" [55].

Future research directions depend on an increase in nonfinancial reports, which will make it possible to get a bigger sample, more companies, and a longer period. Currently, the most important limitation is the number of sustainability reports published according to GRI by European financial services SMEs. Another future research project involves using a proper sample of nonfinancial reports to describe and compare financial sector vs. nonfinancial sector SMEs and financial sector SMEs vs. large financial sector companies.

\section{Conclusions}

These financial services SMEs should particularly focus on the proper elaboration and publication of sustainability reporting. There are many initiatives to increase the importance of this type of company in Europe and to move toward more sustainable finance. There is a challenge for these companies, taking into account all of their stakeholders, to give the proper role to nonfinancial information. It is desirable that SMEs, as well as those that operate in the financial services sector due to their essential role in the economy, start issuing nonfinancial information, especially now, when alternatives to traditional bank financing are being promoted for financing SMEs. These results and conclusions have theoretical and practical implications for the importance of sustainability reporting. It may be a burden, but it can also have multiple advantages, such as being an opportunity to create value in the company, differentiate from other companies, improve operational performance, or enhance market reputation, among others. Our contribution with this work is to point out that these financial services SMEs play an important role, and sustainability reporting has to mean there is another way to do business [78]. This study provides an opportunity to improve sustainability disclosure and standards considering the specific features of financial services SMEs. Regulators must take into account the specific features of this type of company in order to adapt the standards and requirements. Sustainability reports must include all relevant topics that reflect the organization's economic, environmental, and social impacts or influence the decisions of stakeholders [74]. The main reasons argued for not having proper sustainability reporting by SMEs are the lack of resources, awareness of sustainability's importance and potential impacts, access to financing, information and skills to elaborate this information, and regulatory requirements [76]. Thus, this is an opportunity for practitioners, academics, and regulators to try to solve these problems from all points of view, theoretical and practical, to make up for this lack of resources according to their different tasks. Now, when the European Commission is working on amending the nonfinancial reporting directive 
through the mission of the European Financial Reporting Advisory Group (EFRAG) and its Project Task Force on nonfinancial reporting standards, it is time to think about these specific features of SMEs and financial services companies to make the process of sustainability reporting easier.

Author Contributions: Conceptualization, E.O.-M. and S.M.-H.; methodology, E.O.-M. and S.M.-H.; software, E.O.-M.; validation, S.M.; formal analysis, E.O.-M. and S.M.-H.; investigation, E.O.-M. and S.M.-H.; resources, E.O.-M. and S.M.-H.; data curation, E.O.-M. and S.M.-H.; writing-original draft preparation, E.O.-M. and S.M.-H.; writing-review and editing, E.O.; visualization, S.M.-H.; supervision, E.O.-M. and S.M.-H. All authors have read and agreed to the published version of the manuscript.

Funding: This research received no external funding.

Conflicts of Interest: The authors declare no conflict of interest.

\section{References}

1. Directive 2014/95/EU of the European Parliament and of the Council of 22 October 2014 Amending Directive 2013/34/EU as Regards Disclosure of Non-Financial and Diversity Information by Certain Large Undertakings and Groups. Available online: https:/eur-lex.europa.eu/legal-content/EN/TXT/?uri=CELEX\%3A32014L0095 (accessed on 20 May 2019).

2. Lang, M.; Martin, R. The Trickle down Effect-IFRS and accounting by SMEs. European Federation of Accountants and Auditors for SMEs 2017. Available online: http://www.efaa.com/cms/upload/efaa_files/pdf/ Publications/Articles/EFAA_Trickle_Down_WEB.pdf (accessed on 10 July 2020).

3. European Commission. Communication from the Commission to the Council, to the European Parliament, to the Committee of the Regions and to the European and Social Committee. An Action Plan to Improve Access to Finance for SMEs 2011. SEC (2011) 1527final. COM (2011) 870 Final. Available online: https: //eur-lex.europa.eu/LexUriServ/LexUriServ.do?uri=COM:2011:0870:FIN:EN:PDF (accessed on 11 July 2020).

4. Azofra Palenzuela, V.; López Iturriaga, F.J. La Asimetría Informativa En Los Mercados Financieros: ¿el Hallazgo De Un Nexo De Unión? An. Estud. Económicos Empresariales 1996, 11, 9-34.

5. Asteriou, D.; Spanos, K. The relationship between financial development and economic growth during the recent crisis: Evidence from the EU. Financ. Res. Lett. 2019, 28, 238-245. [CrossRef]

6. Palacín-Sánchez, M.-J.; Canto-Cuevas, F.-J.; Di-Pietro, F. Trade credit versus bank credit: A simultaneous analysis in European SMEs. Small Bus. Econ. 2018, 53, 1079-1096. [CrossRef]

7. Glisovic, J.; Martínez, M. Financiamiento de Pequeñas Empresas: ¿Qué papel Desempeñan las Instituciones Microfinancieras? Available online: https://www.cgap.org/sites/default/files/CGAP-Focus-Note-FinancingSmall-Enterprises-What-Role-for-Microfinance-Jul-2012-Spanish.pdf (accessed on 25 July 2020).

8. Feridun, M.; Güngör, H. Climate-related prudential risks in the banking sector: A review of the emerging regulatory and supervisory practices. Sustainability 2020, 12, 5325. [CrossRef]

9. European Commission. Roadmap: Commission Delegated Regulation on Taxonomy-Related Disclosures by Undertakings Reporting Non-Financial Information. 2020. Available online: https://ec.europa.eu/info/law/better-regulation/have-your-say/initiatives/12440-Commission-DelegatedRegulation-on-taxonomy-alignment-of-undertakings-reporting-non-financial-information (accessed on 30 July 2020).

10. Baumann-Pauly, D.; Wickert, C.; Spence, L.J.; Scherer, A.G. Organizing corporate social responsibility in small and large firms: Size matters. J. Bus. Ethics 2013, 115, 693-705. [CrossRef]

11. Dincer, C.; Dincer, B. An investigation of Turkish small and medium-sized enterprises online CSR communication. Soc. Responsib. J. 2010, 6, 197-207. [CrossRef]

12. Torugsa, N.A.; O'Donohue, W.; Hecker, R. Capabilities, proactive CSR and financial performance in SMEs: Empirical evidence from an australian manufacturing industry sector. J. Bus. Ethics 2011, 109, 483-500. [CrossRef]

13. Nin Ho, F.; Wang, H.-M.D.; Ho-Dac, N.; Vitell, S.J. Nature and relationship between corporate social performance and firm size: A cross-national study. Soc. Responsib. J. 2019, 15, 258-274. [CrossRef]

14. Ortiz, E.; Marin, S. Global Reporting Initiative (GRI) as recognized guidelines for sustainability reporting by Spanish companies on the IBEX 35: Homogeneity in their framework and added value in the relationship with financial entities. Intang. Cap. 2014, 10, 855-872. [CrossRef]

15. Albers, C.; Günther, T. Disclose or not disclose: Determinants of social reporting for STOXX Europe 600 firms. Z. Plan. Unternehm. 2010, 21, 323-347. [CrossRef] 
16. Berthelot, S.; Coulmont, M.; Serret, V. Do investors value sustainability reports? A Canadian study. Corp. Soc. Responsib. Environ. Manag. 2012, 19, 355-363. [CrossRef]

17. Cuganesan, S.; Guthrie, J.; Ward, L. Examining CSR disclosure strategies within the Australian food and beverage industry. Account. Forum 2010, 34, 169-183. [CrossRef]

18. Etzion, D.; Ferraro, F. The role of analogy in the institutionalization of sustainability reporting. Organ. Sci. 2010, 21, 1092-1107. [CrossRef]

19. Lopatta, K.; Kaspereit, T. The value relevance of corporate sustainability and sustainability reporting in Europe. SSRN Electron. J. 2011. [CrossRef]

20. Levy, D.L.; Brown, H.S.; De Jong, M. The contested politics of corporate governance. Bus. Soc. 2009, 49, 88-115. [CrossRef]

21. Lynch, B. An examination of environmental reporting by Australian state government departments. Account. Forum 2010, 34, 32-45. [CrossRef]

22. Schadewitz, H.J.; Niskala, M. Communication via responsibility reporting and its effect on firm value in Finland. Corp. Soc. Responsib. Environ. Manag. 2010, 17, 96-106. [CrossRef]

23. González Pérez, M.; Ortiz Martínez, E. Información no financiera y su verificación externa: GRI. Rev. Responsab. Soc. Empresa 2017, 27, 85-106.

24. Dias, A.; Rodrigues, L.L.; Craig, R.; Neves, M.E.D. Corporate social responsibility disclosure in small and medium-sized entities and large companies. Soc. Responsib. J. 2019, 15, 137-154. [CrossRef]

25. Ram, M.; Edwards, P.; Gilman, M.; Arrowsmith, J. The dynamics of informality: Employment relations in small firms and the effects of regulatory change. Work Employ. Soc. 2001, 15, 845-861. [CrossRef]

26. Santos, M.J. CSR in SMEs: Strategies, practices, motivations and obstacles. Soc. Responsib. J. 2011, 7, 490-508. [CrossRef]

27. Bikefe, G.; Zubairu, U.M.; Araga, S.; Maitala, F.; Ediuku, E.; Anyebe, D. Corporate Social Responsibility (CSR) by small and medium enterprises (SMEs): A systematic review. Small Bus. Int. Rev. 2020, 4, 16-33. [CrossRef]

28. Griffin, J.J.; Mahon, J.F. The corporate social performance and corporate financial performance debate. Bus. Soc. 1997, 36, 5-31. [CrossRef]

29. Inoue, Y.; Lee, S. Effects of different dimensions of corporate social responsibility on corporate financial performance in tourism-related industries. Tour. Manag. 2011, 32, 790-804. [CrossRef]

30. Ioannou, I.; Serafeim, G. What drives corporate social performance? International evidence from social, environmental and governance scores. J. Int. Bus. Stud. 2012, 43, 834-864. [CrossRef]

31. Khan, C.H.-U.-Z. The effect of corporate governance elements on corporate social responsibility (CSR) reporting. Empirical evidence from private commercial banks of Bangladesh. Int. J. Law Manag. 2010, 52, 82-109. [CrossRef]

32. Jizi, M.; Salama, A.; Dixon, R.; Stratling, R. Corporate governance and corporate social responsibility disclosure: Evidence from the US banking sector. J. Bus. Ethics 2013, 125, 601-615. [CrossRef]

33. Gambetta, N.; García-Benau, M.A.; Zorio-Grima, A. Corporate social responsibility and bank risk profile: Evidence from Europe. Serv. Bus. 2016, 11, 517-542. [CrossRef]

34. Marín, S.; Gras, E.; Ortiz, E. Prudential regulation and financial information in Spanish banks: 1995-2015. Span. J. Financ. Account. Rev. Española Financ. Contab. 2019, 48, 1-23. [CrossRef]

35. Gallego-Alvarez, I.; Pucheta-Martínez, M.C. Environmental strategy in the global banking industry within the varieties of capitalism approach: The moderating role of gender diversity and board members with specific skills. Bus. Strat. Environ. 2020, 29, 347-360. [CrossRef]

36. Platonova, E.; Asutay, M.; Dixon, R.; Mohammad, S. The impact of corporate social responsibility disclosure on financial performance: Evidence from the GCC Islamic banking sector. J. Bus. Ethics 2016, 151, 451-471. [CrossRef]

37. Esteban-Sanchez, P.; De La Cuesta-Gonzalez, M.; Paredes-Gazquez, J.D. Corporate social performance and its relation with corporate financial performance: International evidence in the banking industry. J. Clean. Prod. 2017, 162, 1102-1110. [CrossRef]

38. Wu, M.-W.; Shen, C.-H.; Chen, T.-H. Application of multi-level matching between financial performance and corporate social responsibility in the banking industry. Rev. Quant. Financ. Account. 2016, 49, 29-63. [CrossRef]

39. Al-Malkawi, H.-A.N.; Pillai, R. Analyzing financial performance by integrating conventional governance mechanisms into the GCC Islamic banking framework. Manag. Financ. 2018, 44, 604-623. [CrossRef]

40. Fijalkowska, J.; Zyznarska-Dworczak, B.; Garsztka, P. Corporate social-environmental performance versus financial performance of banks in central and Eastern European Countries. Sustainability 2018, 10, 772. [CrossRef] 
41. Laguir, I.; Marais, M.; El Baz, J.; Stekelorum, R. Reversing the business rationale for environmental commitment in banking: Does financial performance lead to higher environmental performance? Manag. Decis. 2018, 56, 358-375. [CrossRef]

42. Pérez, A.; Salmones, M.D.M.G.D.L.; Liu, M.T. Maximising business returns to corporate social responsibility communication: An empirical test. Eur. Bus. Rev. 2019, 28, 275-289. [CrossRef]

43. San-Jose, L.; Retolaza, J.L.; Gutierrez-Goiria, J. Are ethical banks different? a comparative analysis using the radical affinity index. J. Bus. Ethics 2011, 100, 151-173. [CrossRef]

44. Tse, T. Shareholder and stakeholder theory: After the financial crisis. Qual. Res. Financ. Mark. 2011, 3 , 51-63. [CrossRef]

45. Shoenmaker, D.; Werkhoven, D. What Is the Appropriate Size of the Banking System? 2012. No. 28. Available online: https://papers.ssrn.com/sol3/papers.cfm?abstract_id=2158606 (accessed on 25 July 2020).

46. McDonald, L.M.; Rundle-Thiele, S. Corporate social responsibility and bank customer satisfaction: A Research Agenda. Int. J. Bank Mark. 2008, 26, 170-182. [CrossRef]

47. Goss, A.; Roberts, G.S. The impact of corporate social responsibility on the cost of bank loans. J. Bank. Financ. 2011, 35, 1794-1810. [CrossRef]

48. European Commission. Consultation Document Review of the Non-Financial Reporting Directive 2020. Available online: https://ec.europa.eu/info/publications/finance-consultations-2020-non-financial-reportingdirective_en (accessed on 10 July 2020).

49. Amor-Esteban, V.; Galindo-Villardón, P.; García-Sánchez, I.-M. A multivariate proposal for a National Corporate Social Responsibility Practices Index (NCSRPI) for international settings. Soc. Indic. Res. 2018, 143, 525-560. [CrossRef]

50. Ortiz, E.; Clavel, J.G. Índices de revelación de información: Una propuesta de mejora de la metodología. Aplicación a la información sobre recursos humanos incluida en los Informes 20F. Rev. Española Financ. Contab. 2006, 35, 87-113. [CrossRef]

51. Bakhtiar, M.; Weekes, B. Lexico-semantic effects on word naming in Persian: Does age of acquisition have an effect? Mem. Cogn. 2014, 43, 298-313. [CrossRef] [PubMed]

52. Marchenko, O.O. A method for automatic construction of ontological knowledge bases. I. Development of a semantic-syntactic model of natural language. Cybern. Syst. Anal. 2016, 52, 20-29. [CrossRef]

53. D'Northwood, G.; Mundy, J. BP plc 2010-A case of linguistic legitimation? J. Appl. Account. Res. 2017, 18, 480-495. [CrossRef]

54. Morales, A. Uso de la Familia Léxica de Sovereignty en los Discursos de la Presidencia del Banco Central Europeo 2003-2016. Available online: http://hdl.handle.net/10201/53021 (accessed on 20 May 2020).

55. Madeira, A.B.; Lopes, M.; Giampadi, V.; Silveira, J.A.G. Análise proposicional quantitativa aplicada. Á pesquisa em administrasao. Quantitative propositional analysis as applied to business administration research. Análisis proposicional cuantitativo aplicado a la investigación en administración. RAE 2011, 51, 396-410.

56. Sohangir, S.; Petty, N.; Wang, D. Financial sentiment lexicon analysis. In Proceedings of the 2018 IEEE 12 th International Conference on Semantic Computing (ICSC), Laguna Hills, CA, USA, 31 January-2 February 2018; pp. 286-289. [CrossRef]

57. Martinez, E.O.; Crowther, D. Is disclosure the right way to comply with stakeholders? The Shell case. Bus. Ethics Eur. Rev. 2007, 17, 13-22. [CrossRef]

58. Nájera-Sánchez, J.-J. A systematic review of sustainable banking through a co-word analysis. Sustainability 2019, 12, 278. [CrossRef]

59. Figueira Marquezau, L.H.; Seibert, R.M.; Bartz, D.; Gomes Barbosa, M.A.; Wickstrom Alves, T. Análise dos Determinantes do disclosure Verde em Relatórios Anuais de Empresas Listadas na BM\&FBOVESPA. Contab. Gest. Gov. Brasilia 2015, 18, 127-150.

60. Fuoli, M. Assessing social responsibility: A quantitative analysis of Appraisal in BP's and IKEA's social reports. Discourse Commun. 2012, 6, 55-81. [CrossRef]

61. Miller, C.V.; Tripp, E.R.; Rasco, M.A. A Linguistic Analysis and Comparison of Hong Kong and US Corporate Governance Reports 2010. Available online: https://digitalcommons.wpi.edu/iqp-all/651 (accessed on 5 April 2020).

62. UN Environment. Sustainability Reporting in the Financial Sector. A Governmental Approach 2017. Available online: https://wedocs.unep.org/handle/20.500.11822/17375 (accessed on 26 April 2020). 
63. GRI. Empowering Small Business. Recommendations for Policy Makers to Enable Corporate Sustainability Reporting for SMEs 2018. Available online: file://C:/Users/UM/Downloads/empowering_small_business_ policy_recommendations\%20(1).pdf (accessed on 22 July 2020).

64. Kaity, M.; Balakrishnan, V. An automatic non-English sentiment lexicon builder using unannotated corpus. J. Supercomput. 2019, 75, 2243-2268. [CrossRef]

65. Kocoń, J.; Miłkowski, P.; Zaśko-Zielińska, M. Multi-level sentiment analysis of PolEmo 2.0: Extended corpus of multi-domain consumer reviews. In Proceedings of the 23rd Conference on Computational Natural Language Learning, Hong Kong, China, 3-4 November 2019; Association for Computational Linguistics: Stroudsburg, PA, USA, 2019; pp. 980-991.

66. Bonsón, E.; Escobar, T. La Difusión Voluntaria de Información Financiera en internet. Un Análisis Comparativo entre Estados Unidos, Europa del Este y la Unión Europea. Rev. Española Financ. Contab. 2004, 33, 1063-1101. [CrossRef]

67. Xiao, J.Z.; Yang, H.; Chow, C.W. The determinants and characteristics of voluntary internet-based disclosures by listed Chinese companies. J. Account. Public Policy 2004, 23, 191-225. [CrossRef]

68. Oyelere, P.; Laswad, F.; Fisher, R. Determinants of internet financial reporting by New Zealand Companies. J. Int. Financ. Manag. Account. 2003, 14, 26-63. [CrossRef]

69. EFAMA. Asset Management in Europe. An Overview of the Asset Management Industry, 11th ed.; EFAMA: Brussels, Belgium, 2019; Available online: https:/www.efama.org/Publications/Statistics/Asset $\% 20$ Management $\%$ 20Report/AssetManagementReport2019.pdf (accessed on 19 June 2020).

70. Sutton, J. Why There Is Not Role for Storytelling in Your Sustainability Report 2017. Available online: https://sustainablebrands.com/read/marketing-and-comms/why-there-is-no-role-for-storytelling-in-yoursustainability-report (accessed on 27 April 2020).

71. Nazari, J.A.; Hrazdil, K.; Mahmoudian, F. Assessing social and environmental performance through narrative complexity in CSR reports. J. Contemp. Account. Econ. 2017, 13, 166-178. [CrossRef]

72. Moreno-Ortiz, A.; Fernandez-Cruz, J. Identifying polarity in financial texts for sentiment analysis: A corpus-based approach. Procedia Soc. Behav. Sci. 2015, 198, 330-338. [CrossRef]

73. Ito, R.; Izumi, K.; Sakaji, H.; Suda, S. Lexicon creation for financial sentiment analysis using network embedding. J. Math. Financ. 2017, 7, 896-907. [CrossRef]

74. GRI IOE. Small Business Big Impact. SME Sustainability Reporting from Vision to Action. Available online: https://www.ioe-emp.org/fileadmin/ioe_documents/publications/Policy\%20Areas/sustainability/ EN/20171113_Small_business_big_impact_-_publication_ENGLISH_version.pdf (accessed on 30 July 2020).

75. Kumar, K.; Prakash, A. Examination of sustainability reporting practices in Indian banking sector. Asian J. Sustain. Soc. Responsib. 2019, 4, 2. [CrossRef]

76. Accountancy Europe. SME Risk Management: Sustainability. Factsheet July 2020. Available online: https: //www.accountancyeurope.eu/publications/sme-risk-management-sustainability/ (accessed on 30 July 2020).

77. KPMG. The Road Ahead. The KPMG Survey of Corporate Responsibility Reporting 2017. Available online: https://integratedreporting.org/wp-content/uploads/2017/10/kpmg-survey-of-corporateresponsibility-reporting-2017.pdf (accessed on 20 April 2020).

78. Alonso, A.; Marqués, J.M. Innovación Financiera para una Economía Sostenible; Documentos Ocasionales; Banco de España: Madrid, Spain, 2019.

(C) 2020 by the authors. Licensee MDPI, Basel, Switzerland. This article is an open access article distributed under the terms and conditions of the Creative Commons Attribution (CC BY) license (http://creativecommons.org/licenses/by/4.0/). 